\title{
An analysis of 37 patients with uterine leiomyosarcoma at a high-volume cancer center
}

\section{Yüksek hacimli bir kanser merkezinde uterin leiomyosarkomlu 37 olgunun analizi}

\author{
Ulaş Solmaz', Levent Dereli², Gülşah Selvi Demirtaş ${ }^{1}$, Atalay Ekin ${ }^{1}$, Emre Mat ${ }^{1}$, Cenk Gezer ${ }^{1}$, \\ Pınar Solmaz Hasdemir1, Sevil Sayhan33, Muzaffer Sancı1, Niyazi Aşkar4 \\ ${ }^{1}$ Tepecik Education and Research Hospital, Clinic of Gynecologic Oncology, İzmir, Turkey \\ ${ }^{2}$ Tavas State Hospital, Clinic of Obstetrics and Gynecology, Denizli, Turkey \\ ${ }^{3}$ Tepecik Education and Research Hospital, Clinic of Pathology, İzmir, Turkey \\ ${ }^{4}$ Ege University Faculty of Medicine, Department of Obstetrics and Gynecology, İzmir, Turkey
}

\begin{abstract}
Objective: To evaluate the clinicopathologic characteristics, treatment methods, survival, and prognosis of uterine leiomyosarcoma (ULMS).

Materials and Methods: All patients with ULMS who were treated between January 1998 and October 2012 were retrospectively reviewed. A total of 37 women who met the inclusion criteria were included in the present study. Univariate and multivariate analyses were used to identify the risk factors for overall survival (OS) and progression-free survival (PFS).

Results: The majority of patients had stage 1 disease (IA, $n=9$ (24.3\%); IB, $n=23$ (62.1\%)). All patients underwent total abdominal hysterectomy and bilateral salpingo-oophorectomy. Additionally, only pelvic, and pelvic plus para-aortic lymphadenectomy was performed in 5 (13.5\%) and 8 (21.6\%) women, respectively. Adjuvant treatment was administered to $27(72.9 \%)$ patients. Patients who did not receive adjuvant therapy had stage 1 disease. Recurrences occurred in 5 (13.5\%) patients. The median follow-up period was 71 months (range 1-158 months). The 5-year PFS and OS rates were $68 \%$ and $74 \%$, for all patients. The 5 -year OS rates for women with stage 1 and $\geq$ stage 2 disease were $82 \%$ and $27 \%$, respectively. Multivariate analysis confirmed stage 1 disease as the only independent predictor of both PFS (Odds ratio (OR) 10.955, 95\% confidence interval (CI) 1.686-71.181, (p=0.012)) and OS (OR 57.429, 95\% CI 3.287-1003.269, ( $\mathrm{p}=0.006)$ ).

Conclusions: Extensive surgery is not associated with prognosis and stage 1 disease is the only independent good prognostic factor for survival in patients with ULMS.

Keywords: Uterine leiomyosarcoma, lymph node dissection, stage, survival

$\ddot{\mathbf{O} z}$

Amaç: Uterin leiomyosarkomun (ULMS) klinikopatolojik özelliklerini, tedavi yöntemlerini, sağkalım özelliklerini ve prognozunu değerlendirmek.

Gereç ve Yöntem: Ocak 1998 ile Ekim 2012 arasında ULMS tanısıyla tedavi verilen tüm hastalar retrospektif olarak değerlendirildi. Dişlama kriterleri sonrasında toplam 37 kadın çalışmaya dahil edildi. Toplam sağkalım (TS) ve progresyonsuz sağkalım (PS) ile ilişkili risk faktörlerini belirlemek üzere tek değişkenli ve çok değişkenli analizler yapıldı.

Bulgular: Hastaların çoğunda evre 1 hastalık mevcuttu (IA, n=9 (\%24,3); IB, n=23 (\%62,1)). Hastaların hepsine total abdominal histerektomi ve bilateral salpingo-ooforektomi yapıldığı görüldü. Ek olarak, sadece pelvik ve hem pelvik hem paraaortik lenfadenektominin sırasıyla 5 (\%13,5) ve 8 (\%21,6) hastada uygulanmış olduğu belirlendi. Adjuvan tedavi $27(\% 72,9)$ hastaya uygulanmıştı. Adjuvan tedavi almayan hastalar evre 1 idi. Beş $(\% 13,5)$ hastada rekürrens saptandı. Ortanca takip periyodu 71 (1-158 ay aralığında) ay olarak bulundu. Tüm hastalar için 5-yıllık PS ve TS oranları sırasılyla \%68 ve \% 74 olarak belirlendi. Evre 1 ve $\geq$ evre 2 hastalarda 5-yıllık TS oranları sırasıyla \%82 ve \%27 idi. Çok değişkenli analizde evre 1 hastalık, PS (Odds oranı (OO)

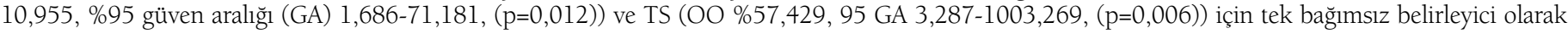
bulundu.
\end{abstract}

Sonuç: ULMS'li hastalarda, ekstensif cerrahi, prognozla ilişkili değildir ve evre 1 hastalık sağkalım için tek bağımsız prognostik faktördür.

Anahtar Kelimeler: Uterin leiomyosarkom, lenf nodu diseksiyonu, evre, sağkalım 


\section{Introduction}

Uterine leiomyosarcomas (ULMSs) are rare malignancies, which constitute approximately $1 \%$ to $3 \%$ of all uterine cancer types(1-3). These tumors are associated with an aggressive clinical course and poor prognosis. Even though these tumors are usually confined to the uterus at the time of diagnosis, high recurrence rates ranging from $45 \%$ to $73 \%$ have been reported(2-4). The reported 5-year overall survival (OS) rates range from $30 \%$ to $42 \%(2-5)$.

Total abdominal hysterectomy (TAH) is the standard approach as an initial therapy for ULMS but the need for additional surgical procedures such as bilateral salpingo-oophorectomy (BSO), pelvic (P) and/or para-aortic (PA) lymphadenectomy and adjuvant therapy is a widely debated issue ${ }^{(5,6)}$. Neither surgical treatment nor postoperative therapy protocols have been completely standardized. In the present study, we evaluated the clinico-pathologic characteristics, prognostic factors, and treatment strategies in 37 patients with ULMS.

\section{Materials and Methods}

\section{Patients}

All patients with ULMS who underwent surgery between January 1998, and October 2012, were retrospectively reviewed. This study was performed in accordance with the ethical standards of the Declaration of Helsinki and was approved by the local ethics committee of our institution. Patients who did not undergo surgery and patients with missing data were excluded. Patients with any other primary cancer were not included in the study.

\section{Data collection}

Demographic data, such as age at diagnosis, parity, surgical and adjuvant treatment details, and follow-up information, were obtained from medical records. Histopathologic findings, including primary tumor diameter (PTD), depth of myometrial invasion (MI), lymphovascular space invasion (LVSI), P and/ or PA lymph node involvement, mitotic counts, cellular atypia, tumor grade, tumor cell necrosis, and the size and location of extra-uterine metastatic tumors were retrieved from surgical pathology reports. All of the pathology slides were reviewed by an experienced gynecologic pathologist using the criteria proposed by Bell et al.,(7) which include the degree of atypia, the presence of necrosis, and mitotic counts.

\section{Surgical technique}

All patients underwent laparotomy. Fluid from peritoneal washing was obtained during surgery for cytologic analysis. TAH with BSO was performed in all patients (some of the patients who underwent myomectomy at initial operation were subsequently re-operated a few weeks later after histologic confirmation of leiomyosarcoma). During the study period, the decision to perform a systematic P and PA lymphadenectomy was made at the surgeon's discretion; no lymph nodes were sampled in some patients, only the P or PA nodes were sampled in some patients, complete staging with bilateral $\mathrm{P}$ lymph node dissection (LND) was applied in some patients, and some patients underwent complete staging with bilateral $\mathrm{P}$ and PA LND. Individual practitioners were responsible for these variations over the study period. Staging criteria were determined postoperatively based on the 2009 International Federation of Gynecology and Obstetrics (FIGO) staging system.

\section{Adjuvant treatment}

Adjuvant therapy, including chemotherapy (CT) alone, radiotherapy (RT, including internal radiotherapy (IRT) and external radiotherapy (ERT)) alone, or a combination of both, was administered to patients based on stage, age, nodal metastasis status, performance status, and the presence/absence of medical comorbidities. The CT regimens were as follows: the ifosfamide, mesna and adriamycin (IMA) regimen, ifosfamidebased regimen, and adriamycin-based regimen. All three regimen were administered intravenously every 21 days to a maximum of 6 cycles. Mesna was given as an intravenous bolus at a dose of $400 \mathrm{mg} / \mathrm{m}^{2}$ before ifosfamide therapy. Ifosfamide and adriamycin were given at a dose of $2500 \mathrm{mg} / \mathrm{m}^{2}$ and 60 $\mathrm{mg} / \mathrm{m}^{2}$, respectively. ERT was administered at a median dose of 50.4 Gy (range, 45-54 Gy) in 1.8-2.0 Gy per fraction, 5 days a week. IRT (2x6.5 Gy and 3x6 Gy when combined with ERT; $3 \times 7$ Gy when applied as the sole RT modality) was delivered via a vaginal applicator fitted with a source of high dose-rate iridium-192.

\section{Clinical follow-up}

The patients returned for follow-up evaluations every 3 months for the first 2 years, every 6 months for the next 3 years, and annually there after. Follow-up evaluations consisted of physical and vaginal examinations, vaginal cytology, ultrasound scanning and assessment of serum CA 125 values. Computed tomography or magnetic resonance imaging was performed annually. Progression-free survival (PFS) was defined as the time from the date of primary surgery to the detection of recurrence or the latest observation. OS was defined as the time interval from the date of surgery to death or last contact.

\section{Statistical analysis}

Statistical analyses were performed using IBM SPSS Statistics 22.0 (SPSS Inc., Chicago, IL). The variables were assessed using visual (histograms, probability plots) and analytical methods to determine whether they were normally distributed. Continuous data (presented as the mean \pm SD and median (min-max)) were analyzed using the Mann-Whitney U test for non-normal data. The Chi-Square test (Pearson's Chi-Square and Pearson's Exact Chi-Square tests) was used to compare the proportions between groups. Univariate and multivariate logistic regression models were used to identify risk factors. The Kaplan-Meier method was used to generate the survival curve, and comparisons were performed with the log rank test. A p-value $<0.05$ was defined as statistically significant. 


\section{Results}

A total of 37 patients with UMLS who fulfilled the inclusion criteria were included. The median age at diagnosis was 52 years (range, 32-71 years), and 25 (67.6\%) patients were postmenopausal. Abnormal vaginal bleeding (67.6\%) was the commonest presentation. Patients had no history of pelvic

Table 1. Clinico-pathologic characteristics with respect to progression-free survival and overall survival

\begin{tabular}{|c|c|c|c|}
\hline Characteristics & n (\%) & $\begin{array}{l}p \text { value } \\
\text { for PFS }\end{array}$ & $\begin{array}{l}p \text { value } \\
\text { for OS }\end{array}$ \\
\hline $\begin{array}{l}\text { Age (years) } \\
<52 \\
\geq 52\end{array}$ & $\begin{array}{l}18(48.6) \\
19(51.4)\end{array}$ & 0.061 & 0.150 \\
\hline $\begin{array}{l}\text { Symptom } \\
\text { Vaginal bleeding } \\
\text { Pelvic pain } \\
\text { Pelvic mass }\end{array}$ & $\begin{array}{l}25(67.5) \\
2(5.4) \\
10(27.1)\end{array}$ & 0.728 & 0.742 \\
\hline $\begin{array}{l}\text { Menopausal status } \\
\text { Yes } \\
\text { No }\end{array}$ & $\begin{array}{l}24(64.9) \\
13(35.1)\end{array}$ & 0.287 & 0.425 \\
\hline $\begin{array}{l}\text { Clinical stage } \\
1 \\
2-4\end{array}$ & $\begin{array}{l}32(86.5) \\
5(13.5)\end{array}$ & 0.04 & 0.06 \\
\hline $\begin{array}{l}\text { Maximal tumor diameter } \\
1-5 \mathrm{~cm} \\
5-10 \mathrm{~cm} \\
>10 \mathrm{~cm}\end{array}$ & $\begin{array}{l}8(21.6) \\
17(45.9) \\
12(32.4)\end{array}$ & 0.388 & 0.761 \\
\hline $\begin{array}{l}\text { Lymph node resection } \\
\text { Yes } \\
\text { No }\end{array}$ & $\begin{array}{l}12(22.5) \\
25(67.5)\end{array}$ & 0.793 & 0.451 \\
\hline $\begin{array}{l}\text { Necrosis } \\
\text { Yes } \\
\text { No } \\
\text { Not available }\end{array}$ & $\begin{array}{l}19(51.4) \\
17(45.9) \\
1\end{array}$ & 0.03 & 0.07 \\
\hline $\begin{array}{l}\text { Mitotic count per } 10 \mathrm{HPF} \\
<10 \\
\geq 10\end{array}$ & $\begin{array}{l}19(51.4) \\
18(49.6)\end{array}$ & 0.06 & 0.085 \\
\hline $\begin{array}{l}\text { Nuclear atypia } \\
\text { Yes } \\
\text { No }\end{array}$ & $\begin{array}{l}20(54.1) \\
17(45.9)\end{array}$ & 0.437 & 0.637 \\
\hline $\begin{array}{l}\text { Adjuvant treatment } \\
\text { No } \\
\text { Yes } \\
\text { Only RT } \\
\text { Only CT } \\
\text { Combination }\end{array}$ & $\begin{array}{l}10(27.1) \\
27(72.9) \\
13(35.1) \\
2(5.4) \\
12(32.4)\end{array}$ & 0.001 & 0.045 \\
\hline
\end{tabular}

CT: Chemotherapy, RT: Radiotherapy, PFS: Progression-free survival, OS: Overall survival. Values for continuous variables are medians (min-max). Values for categorical variables are number/total number of cases (\%). A p-value $<0.05$ was considered statistically significant irradiation before diagnosis. Thirty-two patients (86.5\%) presented with FIGO stage 1 disease (IA, $n=9$ (24.3\%); IB, $\mathrm{n}=23(62.1 \%)), 2$ (5.4\%) with stage 2 disease, and $3(8.1 \%)$ with stage 4 disease. The demographic and clinico-pathologic characteristics are summarised in Table 1.

A total of 28 (75.7\%) patients had a history of diagnostic dilatation and curettage (D\&C) preoperatively, and only 3 had malignant histopathology. Of the remaining 9 (24.3\%) patients who did not undergo D\&C; 3 (8.1\%) had pathologic confirmation after myomectomy, and 31 (83.7\%) patients were diagnosed as having leiomyosarcoma after hysterectomy was performed for suspected benign disease. Among the 37 patients, 24 (64.9\%) underwent $\mathrm{TAH}+\mathrm{BSO}, 5$ (13.5\%) underwent $\mathrm{TAH}+\mathrm{BSO}$ and $\mathrm{P}$ lymphadenectomy, and 8 (21.6\%) underwent $\mathrm{TAH}+\mathrm{BSO}$ and $\mathrm{P}$ plus PA lymphadenectomy. Adjuvant treatment was administered to 27 patients (72.9\%); 2 patients $(5.4 \%)$ received CT alone, 13 patients $(35.1 \%)$ received only RT, and 12 (32.4\%) received both RT and CT. The 10 (27.1\%) patients who did not receive adjuvant therapy had stage 1 disease.

PTD were $<5 \mathrm{~cm}$ in 8 (21.6\%) patients, $>10 \mathrm{~cm}$ in $12(32.4 \%)$ patients, and between $5-10 \mathrm{~cm}$ in 17 (45.9\%) patients. Tumor necrosis was present in 19 (51.4\%) patients. Two (13.5\%) patients had lung metastasis alone, and 1 patient had both inguinal lymph node and lung metastasis.

In the present study, the univariate analysis found that stage (stage 1 vs. stage $\geq 2$ ), and absence of tumor necrosis were the significant prognostic factors for PFS $(p=0.04$, and $p=0.03$, respectively). Adjuvant therapy (yes vs. no) was the only significant prognostic factor for both PFS and OS $(p=0.001$, and $\mathrm{p}=0.045$, respectively). Multivariate analysis confirmed that disease confined to the uterus (stage 1) was the only independent predictor of both PFS (Odds ratio (OR) 10.955, 95\% confidence interval (CI) 1.686-71.181, ( $\mathrm{p}=0.012))$ and OS (OR 57.429, 95\% CI 3.287-1003.269, ( $\mathrm{p}=0.006)$ ).

The median follow-up period was 71 months (range, 1-158 months). Recurrence developed in 5 (13.5\%) patients, of whom 4 had stage $1 \mathrm{~B}$ disease, and 1 had stage 2 disease. There was only one vaginal cuff recurrence. The rest of the recurrences were outside the $\mathrm{P}$ cavity ( 3 had lung recurrence, 1 had both omental and lung recurrences). The median PFS and OS for all patients were 50 months (range, 1-148 months) and 71 months (range, 7-158 months), respectively. The median OSs for women with stage 1 and $\geq$ stage 2 disease were 59 months (range, 7-158 months) and 24 months (range, 9-71 months), respectively (Figure 1, 2). The 5-year PFS and OS rates for all patients were $68 \%$ and $74 \%$, respectively. The 5 -year OS rates for women with stage 1 and $\geq$ stage 2 disease were $82 \%$ and $27 \%$, respectively.

\section{Discussion}

ULMSs are rare and rather aggressive tumors that have poor outcomes with early-onset extra-uterine metastases and distant recurrences(3). 
Many clinico-pathologic variables such as age at diagnosis, menopausal status, race, stage, grade (nuclear atypia), mitotic counts, PTD, and lymph node status were studied for any potential prognostic impact in women with ULMS. Among these, the most common accepted prognostic factors were

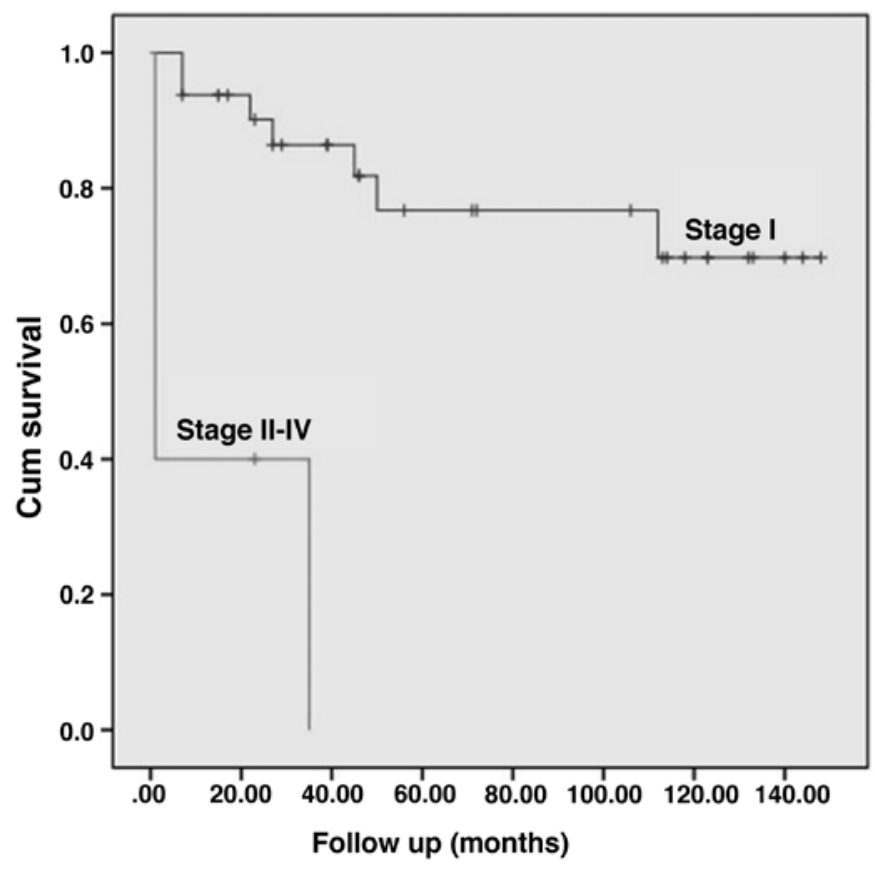

Figure 1. Progression-free survival rates of patients were grouped according to FIGO stage (stage 1 and stage 2-4)

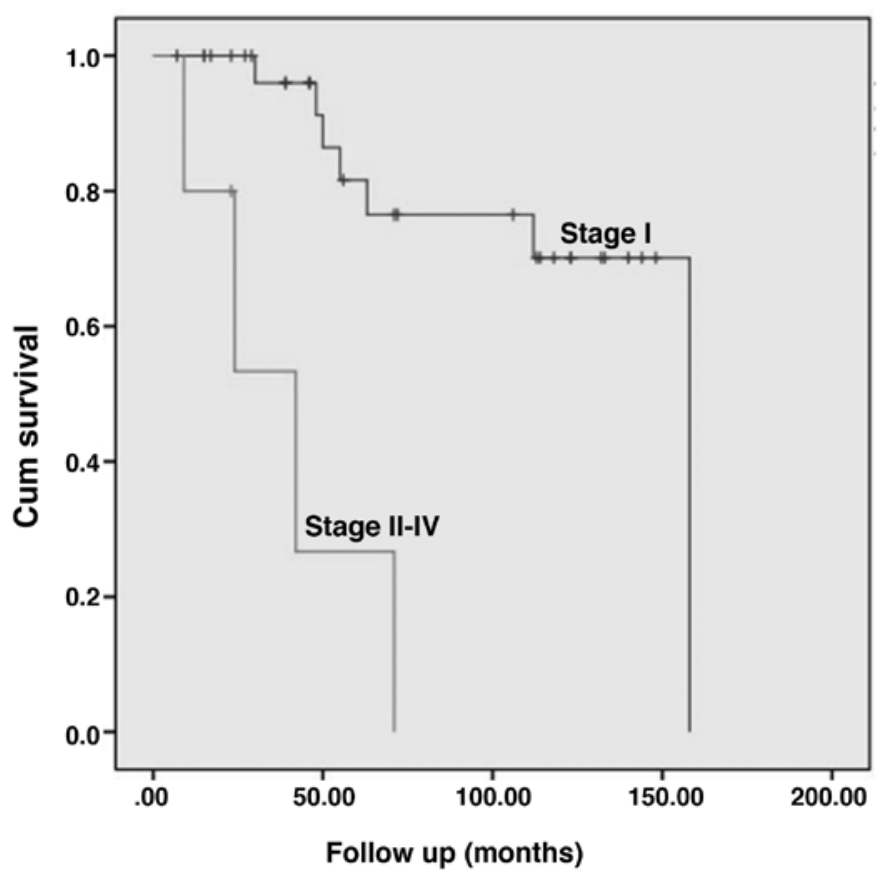

Figure 2. Overall survival rates of patients were grouped according to FIGO stage (stage 1 and stage 2-4) stage and nuclear atypia(5,8-15). In the present study, stage 1 disease was found to be an independent favorable prognostic factor for both OS and PFS. However, nuclear atypia did not reach statistical significance as a poor prognostic factor. Mitotic counts $>15$ per 10 high-power fields (HPF) were reported to be a significant factor of poor prognosis on univariate analysis by Wu et al.(15) Pautier et al.(11) reported that stage and mitotic counts were the only factors that reached statistical significance in predicting both OS and PFS on multivariate analysis. In another study, higher mitotic activities per any HPF were associated with a decrease in survival. Grade did not have an impact on survival and the absence of necrosis was a favorable prognostic feature(16). The association between necrosis and PFS was first described by Hsieh et al.(8) In line with some above mentioned studies, we found that tumor necrosis was associated with poor PFS.

Total abdominal hysterectomy is the standard approach as an initial therapy for ULMS but the need for additional surgical procedures such as $\mathrm{BSO}, \mathrm{P}$ and/or PA lymphadenectomy and adjuvant therapy is a widely debated issue. Apparently, in line with the results of some studies in the literature, there is no clear benefit in performing salpingo-oophorectomy and/or lymph node dissection in patients with ULMS $(5,6)$. Hsieh et al.(8) observed that relapse occured in 1 out of 5 patients (20\%) with stage 1 disease who underwent $\mathrm{TAH}+\mathrm{BSO}$ and 1 out of 6 patients (16.7\%) with stage 1 disease, in whom one or both ovaries were left behind.

The incidence of lymphatic spread is only about 3\% in earlystage $\operatorname{ULMS}(10,17,18)$. Ayhan et al.(2) reported that neither performing lymphadenectomy nor extent of lymph node dissection (number of resected lymph nodes) has significant effects on both PFS and OS in such patients. However, they emphasized that lymphadenectomy could be considered for patients with extrauterine involvement, clinically suspicious nodes or in postmenopausal women with enlarged uterus or large tumor. In contrast, Leibsohn et al.(19) highlighted the impact of primary tumor diameter and reported a 50\% rate of lymph node metastasis in women with tumors measuring 6-10 $\mathrm{cm}$. Kapp et al.(5) demonstrated that the incidence of regional lymph node metastasis was low and salpingo-oopherectomy did not improve survival. In the present study, in addition to $\mathrm{TAH}+\mathrm{BSO}$, P plus PA lymphadenectomy was performed in 8 (21.6\%) patients, and $4(10.8 \%)$ patients underwent only $\mathrm{P}$ lymphadenectomy. There were neither P nor PA lymph node metastasis. Additionally, we found no statistically significant difference in terms of survival between patients in the lymphadenectomy and no lymphadenectomy groups.

Abrahao and Maluf reported a case of ULMS that had metastasized to the central nervous system. The authors emphasised that ULMS primarily spreads hematogenously and as in our study, the most common site of distant metastasis was lung. Consequently, a chest X-ray or a computerized tomography should be performed as a part of initial staging(20). 
As well as extensive surgery, the role of adjuvant CT is controversial. A study of doxorubicin alone demonstrated no benefit in survival(21). On the other hand, a study by Hensley et al.(22) combination CT with gemcitabine, docetaxel, and doxorubicin has increased expectations of adjuvant CT treatment in such patients. In another study by Wong et al.(23) it was reported that postoperative pelvic RT reduced recurrence and had a significant effect on OS. In contrast, Reed et al.(24) showed that adjuvant RT was not associated with improved survival in women with stage 1 and 2 disease. Additionally, Yu et al.(25) reported that pelvic RT had no beneficial effects on survival and distant control. They also emphasized that CT must be the corner stone of adjuvant therapy. Conversely, in the present study both adjuvant treatment modalities significantly prolonged PFS and OS. Finally, in our study the 5-year PFS and OS rates for all patients were higher (68\% and $74 \%$, respectively) than the survival rates in most studies (45$73 \%$ and $10-73 \%$, respectively) $(2-5,9,10,15,16,26-29)$. This was probably due to the higher proportion of patients who were diagnosed at stage 1 .

The limitations of this study are its retrospective nature, and some patients were treated by non-gynecologic oncologic surgeons and therefore patients were treated with different types of surgical approaches over the 15-year time period. Retrospective cohort studies are subject to selection bias, recall bias, and unknown confounding variables, which may negatively impact the accuracy of the results. Moreover, during the 15-year study period, significant improvements in surgical techniques and adjuvant treatment may have also affected the results. Lastly, the data did not allow for definitive and comparative analyses to assess the heterogeneity of the different adjuvant therapy regimens. Despite these limitations, the relatively large number of patients diagnosed as having this rare disease, with similar demographic characteristics was included in this study. In addition, good follow-up data were available. Additionally, the surgeries were performed at a single institution, and all pathologic slides were reviewed by an experienced gynecologic pathologist. All of these factors most likely increased the validity of the results and mitigated the limitations.

In conclusion, our study demonstrated stage 1 disease to be the only independent prognostic factor for survival in women with ULMS. Surgery remains the primary treatment modality. Spread of ULMS is mainly hematogenous so extensive surgery including lymphadenectomy appears to be of less importance. Therefore, quality of life issues, operability, and the most appropriate and effective treatment regimens should also be considered for management. Further improvements in survival rates require the optimization of adjuvant therapy modalities.

Ethics Committee Approval: This study was approved by the Tepecik Education and Research Hospital of Local Ethics Committee, Informed Consent: Consent form was filled out by all participants, Concept: Ulaş Solmaz, Atalay Ekin, Niyazi
Aşkar, Design: Ulaş Solmaz, Muzaffer Sancı, Levent Dereli, Data Collection or Processing: Pinar Solmaz Hasdemir, Emre Mat, Levent Dereli, Cenk Gezer, Analysis or Interpretation: Sevil Sayhan, Ulaş Solmaz, Gülşah Selvi Demirtaş, Literature Search: Ulaş Solmaz, Pınar Solmaz Hasdemir, Gülşah Selvi Demirtaş, Writing: Ulaş Solmaz, Peer-rewiev: External and Internal peer-reviewed, Conflict of Interest: No conflict of interest was declared by the authors, Financial Disclosure: The authors declared that this study has received no financial support.

\section{References}

1. Zivanovic O, Leitao MM, Iasonos A, Jacks LM, Zhou Q, AbuRustum NR, et al. Stage-Specific outcomes of patients with uterine leiomyosarcoma: A comparison of the International Federation of Gynecology and Obstetrics and American Joint Committee on Cancer Staging Systems. J Clin Oncol 2009;27:2066-72.

2. Ayhan A, Aksan G, Gultekin M, Esin S, Himmetoglu C, Dursun P, et al. Prognostic factors and the role of lymphadenectomy in uterine leiomyosarcomas. Arch Gynecol Obstet 2009;280:79-85.

3. Goff BA, Rice LW, Fleischhacker D, Muntz HG, Falkenberry SS, Nikrui $\mathrm{N}$, et al. Uterine leiomyosarcoma and endometrial stromal sarcoma: lymph node metastases and sites of recurrence. Gynecol Oncol 1993;50:105-9

4. Tasci T, Karalok A, Taskin S, Ureyen I, Kımyon G, Tulek F, et al. Does lymphadenectomy improve survival in uterine leiomyosarcoma? Int J Gynecol Cancer 2015;25:1031-6.

5. Kapp DS, Shin JY, Chan JK. Prognostic factors and survival in 1,396 patients with uterine leiomyosarcomas: emphasis on impact of lymphadenectomy and oophorectomy. Cancer 2008;112:820-30.

6. D'Angelo E and Prat J. Uterine sarcomas: a review. Gynecol Oncol 2010;116:131-9.

7. Bell SW, Kempson RL, Hendrickson MR. Problematic uterine smooth muscle neoplasms. A clinicopathologic study of 213 cases. Am J Surg Pathol 1994;18:535-58.

8. Hsieh CH, Lin H, Huang CC, Huang EY, Chang SY, Chang Chien CC. Leiomyosarcoma of the uterus: a clinicopathologic study of 21 cases. Acta Obstet Gynecol Scand 2003;82:74-81

9. Major FJ, Blessing JA, Silverberg SG, Morrow CP, Creasman WT, Currie JL, et al. Prognostic factors in early stage uterine sarcoma. Cancer 1993;71:1902-9.

10. Giuntoli RL 2nd, Metzinger DS, DiMarco CS, Cha SS, Sloan JA, Keeney Gl, et al. Retrospective review of 208 patients with leiomyosarcoma of the uterus: prognostic indicators, surgical management, and adjuvant therapy. Gynecol Oncol 2003;89:460-9.

11. Pautier P, Genestie C, Rey A, Morice P, Roche B, Lhommé C, et al. Analysis of clinicopathologic prognostic factors for 157 uterine sarcomas and evaluation of a grading score validated for soft tissue sarcoma. Cancer 2000;88:1425-31.

12. Evans HL, Chawla SP, Simpson C, Finn KP. Smooth muscle neoplasm of the uterus other than ordinary leiomyoma: a study of 46 cases, with emphasis on diagnostic criteria and prognostic factor. Cancer 1988;62:2239-47.

13. Larson B, Silfversward C, Nilsson B, Petterson F. Prognostic factors in uterine leiomyosarcoma: a clinicopathologic study of 143 cases. The Radiumhemmet series, 1936-1981. Acta Oncol 1990;29:185-91.

14. LayWeld LJ, Liu K, Dodge R, Barsky SH. Uterine smooth muscle tumor: utility of classification by proliferation, ploidy and prognostic markers versus traditional histopathology. Arch Pathol Lab Med 2000;124:221-7. 
15. Wu TI, Chang TC, Hsueh S, Hsu KH, Chou HH, Huang HJ, et al. Prognostic factors and impact of adjuvant chemotherapy for uterine leiomyosarcoma. Gynecol Oncol 2006;100:166-72.

16. Dinh TV, WoodruV JD. Leiomyosarcoma of the uterus. Am J Obstet Gynecol 1982;144:817-23

17. Gadducci A, Cosio S, Romanini A, Genazzani A. The management of patients with uterine sarcoma: a debated clinical challenge. Crit Rev Oncol Hematol 2008;65:129-42.

18. Vrzic-Petronijevic S, Likic-Ladjevic I, Petronijevic M, Argirovic R, Lad-Jevic N. Diagnosis and surgical therapy of uterine sarcoma. Acta Chir Lugosl 2006;53:67-72.

19. Leibsohn D, d'Ablaing G, Mishrll DRJr, Schlaerth JB. Leiomyosarcoma in a series of hysterectomies performed for presumed uterine leiomyomas. Am J Obstet Gynecol 1990;162:968-74.

20. Abrahao CM, Maluf FC. Uterine leiomyosarcoma with central nervous system metastases. Ecancermedicalscience 2015;9:515.

21. Zagouri F, Dimopoulos AM, Fotiou S, Kouloulias V, Papadimitriou CA. Treatment of early uterine sarcomas: disentangling adjuvant modalities. World J Surg Oncol 2009;7:38.

22. Hensley M, Wathen J, Maki R, Anrojo DM, Sutton DA, Priebat DA, et al. Adjuvant therapy for high-grade, uterus-limited leiomyosarcoma: Results of a phase 2 trial (SARC005). Cancer 2013;119:1555-61.
23. Wong P, Han K, Sykes J, Catton C, Laframboise S, Fyles A, et al. Postoperative radiotherapy improves local control and survival in patients with uterine leiomyosarcoma. Radiat Oncol 2013;8:128.

24. Reed, N. The management of uterine sarcomas. Clin Oncol (R Coll Radiol) 2008;20:470-8.

25. Yu T, Kim HJ, Wu HG, Ha SW, Song YS, Park NH, et al. Outcome analysis in patients with uterine sarcoma. Radiat Oncol J 2015;33:29-35.

26. Gadducci A, Landoni F, Sartori E, Zola P, Maggino T, Lissoni A, et al. Uterine leiomyosarcoma: analysis of treatment failures and survival. Gynecol Oncol 1996;62:25-32.

27. Mayerhofer K, Oberm air A, Windbichler G, Petru E, Kaider A, Hefler L, et al. Leiomyosarcoma of the uterus: a clinicopathologic multicenter study of 71 cases. Gynecol Oncol 1999;74:196-201.

28. Akahira J, Tokunaga H, Toyoshima M, Takano T, Nagase S, Yoshinaga $\mathrm{K}$, et al. Prognoses and prognostic factors of carcinosarcoma, endometrial stromal sarcoma and uterine leiomyosarcoma: a comparison with uterine endometrial adenocarcinoma. Oncology 2006;71:333-40.

29. Dinh TA, Oliva EA, Fuller AF Jr, Lee H, Goodman A. The treatment of uterine leiomyosarcoma. Results from a 10-year experience (1990-1999) at the Massachusetts General Hospital. Gynecol Oncol 2004;92:648-52. 